\title{
Synthetic biology yields a dinuclear copper based antibody for the naked-eye detection of glyphosate
}

\author{
Marc Creus $^{1 *}$ and Thibaud Rossel ${ }^{2 \dagger}$ \\ ${ }^{1}$ University of Basel, Klingelbergstrasse 50/70, 4056, Basel, Switzerland \\ ${ }^{2}$ Chemistry, Gymnase français de Bienne, Pré Jean-Meunier 1, Moutier, 2740, \\ Switzerland
}

\begin{abstract}
The design and construction of synthetic antibodies capable of recognizing selectively antigens is an important challenge for synthetic biology and bio-engineering. Here, we develop a step towards the construction of de novo synthetic antibodies using a new combinatorial based approach. The bioconstruct incorporates supramolecularly a self assembling inorganic complex into a protein thus creating a modular and evolvable receptor. We used a dinuclear copper based inhibitor of carbonic anhydrase to program host-guest recognition, which in the presence of glyphosate generates a selective naked-eye sensing. The construct was used to detect the pesticide in complex samples. Taken together, our results provide new opportunities for the combinatorial optimization and evolution of our synthetic antibodies. Our assay is geared and designed specifically towards the mimic of natural antibodies but with features reminiscent of both synthetic biology and inorganic chemistry. In the near future, we anticipate evolution and artificial intelligence protocols dedicated to fine tune our host for the optimal recognition of a multitude of analytes.
\end{abstract}

Key words: copper, indicator displacement assay, carbonic anhydrase, pyrocathecol violet, glyphosate

\section{Introduction}

The development of bio-compatible synthetic antibodies [1] capable of modular and evolvable specific chemical and naked-eye recognition [2] is an important challenge for synthetic biology [3] and bio-engineering. Natural antibodies are the gold standard of exquisite recognition for all sorts of applications, such as for example: sensing or immunotherapies. [4] These applications exploit bio-chemically modified natural antibodies as bio-synthetic receptor rather than taking advantage of the de novo design of completely

\footnotetext{
*E-mail: marc.creus@unibas.ch

${ }^{\dagger}$ E-mail: thibaud.rossel@emsp.gfbienne.ch
} 
new to nature receptors with additional fundamental functions and features. [5, 6] In this regard, recent advances in the design and construction of artificial chemical receptors have produced a platform of alternative technologies for preparing sensing objects featuring robustness, affinity, selectivity and low detection limits but not with all these qualities necessarily reunified. Some of the best example of such challengers are: aptamers [7], cyclophanes [8], calixarene [9], crown ether [10] and cryptand [11], container molecules [12], calixarene [13] or boronic acids [14]. However, these receptors most of the time take only advantage of the first coordination sphere for recognition instead of exploring the interaction possibilities of the second coordination sphere for recognition. For example, in some antibodies such as Sonepcizumab recognizing sphyngosine-1-phosphate (S1P, see Figure 1) $[15,16]$, the exquisite selectivity is due to first and second coordination sphere interactions. The phosphorylated part of S1P is coordinated to the dinuclear calcium based epitope whereas the tail is confined in a tunnel built by the proteic environnement (seeFigure 1)

a)

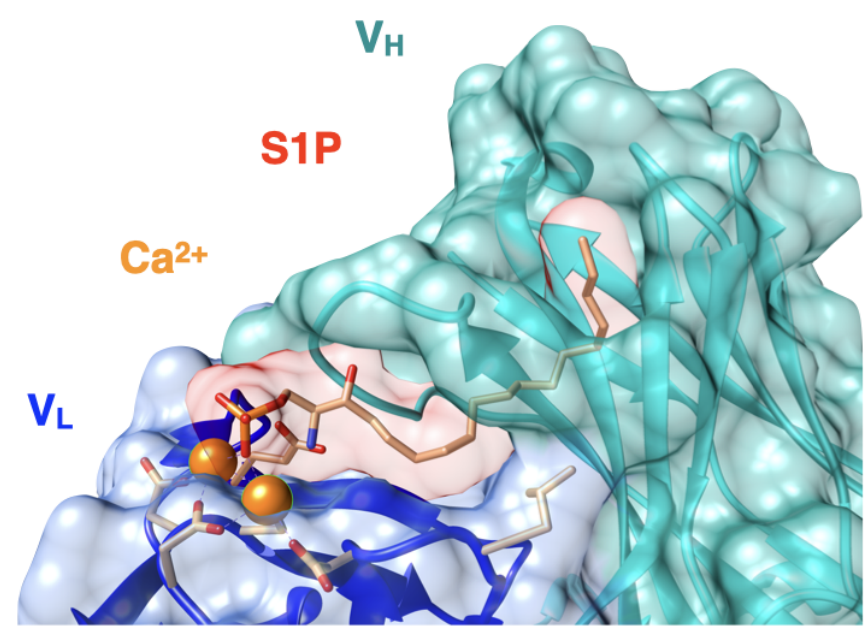

b)<smiles>CCCCCCCCCCCCC/C=C/C(O)C(N)COP(=O)([O-])[O-]</smiles>

FIGURE 1: Sonepcizumab in association with sphyngosine-1-phosphate (S1P), the phosphate moiety is coordinated to the dinuclear copper epitope whereas the tail of the phospholipid is confined in an aminoacid tunnel shaped cavity b) Lewis structure of S1P

Therefore, inspired by the mode of binding to the phosphate moiety of the sonecizumab antibody, we sought to design a biomimetic receptor of glyphosate based on a bi-metallic bioinorganic complex. Furthermore, we sought to exploit this synthetic antibody of glyphosate to develop an easy and inexpensive assay for its detection through the development of an indicator displacement assay (IDA) into a protein (carbonic an- 
hydrase). Glyphosate, is a world widely used chemical herbicide in agriculture contaminating soil, water and organisms. [17] It has attracted increasing attention over the past decades due to its presumed toxicity generating various diseases such as for example: cancers, neuropathy, obesity, infections, infertility, birth defects, etc. [17] [17]

Here we report on the first IDA for glyphosate based on the dinuclear complex $\left[\mathrm{Cu}_{2}(\mathrm{HXTA}-\mathrm{ArS})(\mathrm{PCV})\right]^{3-}$ incorporated into carbonic anhydrase that mimics the first and the second coordination sphere of the metal-mediated binding of an anti-S1Pantibody. It proved useful for the selective naked-eye detection of glyphosate over other molecules thus taking advantage of first and second coordination sphere.

\section{Materials and methods}

\subsection{Ligand synthesis}

Ligand synthesis was performed by Chiroblock Germany. The ligand was synthesized in two steps. As initial step, an arylboronic sulfonamid was used (1) for suzuki coupling with bromocresol (2) yielding the corresponding the biarylphenol sulfonamid (3). As a final step, the biarylphenol sulfonamide (3) was reacted with iminodiacetic acid (4) to yield the final product HXTA-ArS- $\mathrm{H}_{5}$ using a Mannich reaction and purified by reversed phase HPCL. (SeeFigure 2)

\subsection{Complex synthesis}

Dissolving HXTA-ArS- $\mathrm{H}_{5}(20 \mu \mathrm{M})$ and copper chlorate $\left(40 \mu \mathrm{M}, \mathrm{Cu}\left(\mathrm{ClO}_{4}\right)_{2}\right)$ in 2-[4(2-hydroxyethyl)-1-piperazinyl] ethanesulfonic acid (HEPES, $100 \mathrm{mM}, \mathrm{pH}=7.4$ ) formed $\left[\mathrm{Cu}_{2}(\mathrm{HXTA}-\mathrm{ArS})\right]^{1-}$, which is water-soluble and pale green at working micromolar concentrations. Record of an absorbance spectra allows to determine an absorbance band at $455 \mathrm{~nm}$ as described in the litterature for $\left[\mathrm{Cu}_{2}(\mathrm{HXTA})\right]$ [18]. (See Figure 2 )

\subsection{Synthetic antibody synthesis}

By analogy with sonecizumab (seeFigure 1 ) we hypothesized that the $\left[\mathrm{Cu}_{2}(\mathrm{HXTA}-\right.$ ArS) $]^{1-}$ complex could be used to assemble an artificial receptor by incorporation of the cofactor into carbonic anhydrase forming $\left[\mathrm{Cu}_{2} \text { (HXTA-ArS) }\right]^{1-} \subset \mathrm{CA}(20 \mu \mathrm{M})$. To the best of our knowledge, this dinuclear complex has never before been described in the literature as cofactor incorporated into proteins for the creation of a synthetic antibody. The creation of the receptor mimic is illustrated schematically in Figure 2. The ensemble was prepared by simply by mixing $\mathrm{HXTA}-\mathrm{ArS}-\mathrm{H} 5, \mathrm{Cu}\left(\mathrm{ClO}_{4}\right)_{2}$ and carbonic anhydrase (bCA or hCAII) in a 1:2:1 molar ratio in an aqueous solution of $100 \mathrm{mM}$ HEPES buffer $\mathrm{pH}$ $=7.4$. Addition of pyrocathecol violet to the homoleptic complex $\left[\mathrm{Cu}_{2}(\mathrm{HXTA}-\mathrm{ArS})\right]^{1-}$ formed the heteroleptic complex $\left[\mathrm{Cu}_{2} \text { (HXTA-ArS)(PCV) }\right]^{3-}$ with an affinity constant for PCV of $\mathrm{K}_{a}=3.77 \bullet 10^{6} \mathrm{M}^{-1}$ (See Table 1).

With selective colorimetric detection in mind we sought to test our receptor against phosphate derivatives such as glyphosate and various anions. Screening of the receptor allowed to detect both glyphosate and pyrophosphate with a concomitant color 
a)

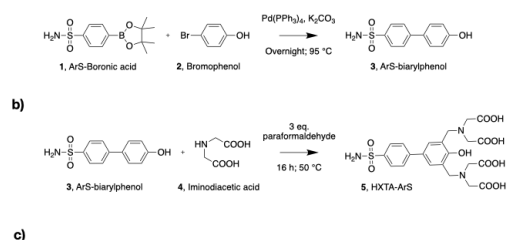

c)

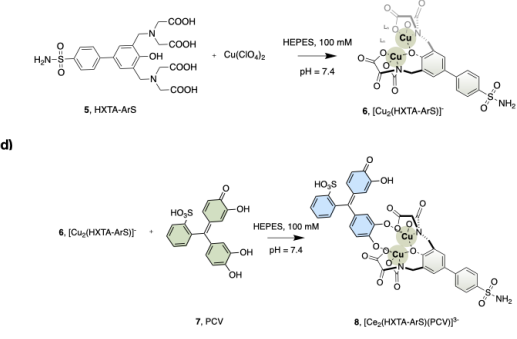

e)
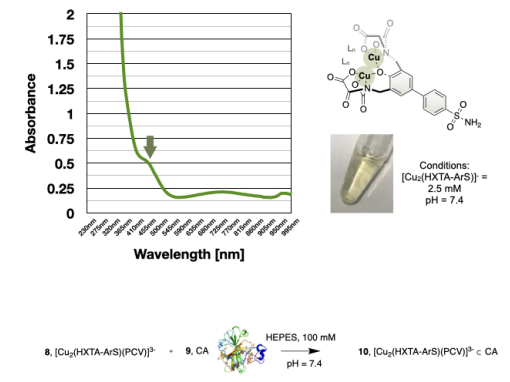

g)
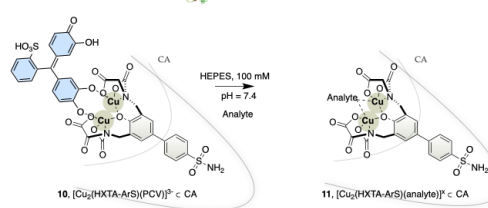

FIGURE 2: a) First step of the ligand synthesis using a suzuki coupling b) Second step synthesis of the ligand using a Mannich reaction c) mixing HXTA-ArS- $\mathrm{H}_{5}$ (5, $20 \mu \mathrm{M})$ with copper chlorate $(20 \mu \mathrm{M})$ in HEPES $100 \mathrm{mM} \mathrm{pH}=7.4$ forms a pale green complex of $\left[\mathbf{6}, \mathrm{Cu}_{2}(\mathrm{HXTA}-\mathrm{ArS})\right]^{-}$. d) addition of pyrocathecol violet $(7,20$ $\mu \mathrm{M})$ to $\left[6, \mathrm{Cu}_{2}(\mathrm{HXTA}-\mathrm{ArS})\right]^{-}$forms an heteroleptic blue complex [7, $\mathrm{Cu}_{2}(\mathrm{HXTA}-$ $\mathrm{ArS})(\mathrm{PCV})]^{3-}$. e) Absorbance spectra of $\left[\mathrm{Cu}_{2}(\mathrm{HXTA}-\mathrm{ArS})\right]^{1-}$ at $2.5 \mathrm{mM}$. f) Addition of $\left[\mathbf{6}, \mathrm{Cu}_{2}(\mathrm{HXTA}-\mathrm{ArS})\right]^{-}$to carbonic anhydrase (hCAII or bCA) offers $\left[\mathbf{8}, \mathrm{Cu}_{2}(\mathrm{HXTA}-\right.$ $\left.\mathrm{ArS})(\mathrm{PCV})]^{3-}\right] \subset \mathrm{CA}$, the synthetic antibody g) Addition of the analyte (glyphosate) to [8, $\mathrm{Cu}_{2}$ (HXTA-ArS)(PCV) $\left.]^{3-}\right] \subset \mathrm{CA}$ allows an indicator displacement assay for the nakedeye recognition of the pesticide.

change (See Figure 4). The first coordination sphere of the receptor was not sufficient for selective recognition of phosphate derivatives. Interestingly, phosphate was not sensed by our host. It is also interesting to mention that copper dinuclear complexes are reported for the naked-eye detection of pyrophosphate but were not tested for glyphosate such as for exemple the dinuclear copper based complex build with the bis-2-((pyridin-2-ylmethylamino)- methyl)phenol ligand. [19] Finally, titration of $\left[\mathrm{Cu}_{2} \text { (HXTA-ArS)(PCV) }\right]^{3-}$ with glyphosate allowed an indicator displacement assay with an affinity constant for glyphosate of $\mathrm{K}_{a}=7.02 \cdot 10^{6} \mathrm{M}^{-1}$ (SeeTable 1).

Reassured by the detection of glyphostate, we incorporated $\left[\mathrm{Cu}_{2}(\mathrm{HXTA}-\mathrm{ArS})(\mathrm{PCV})\right]^{3-}$ into carbonic anhydrase to form $\left[\mathrm{Cu}_{2}(\mathrm{HXTA}-\mathrm{ArS})(\mathrm{PCV})\right]^{3-} \subset$ bCA. The addition of $\left[\mathrm{Cu}_{2} \text { (HXTA-ArS)(PCV) }\right]^{3-}$ into carbonic anhydrase allowed an hypsochromic shift from pale blue to blue ( 435 to $435 \mathrm{~nm}$ ) (See Figures 2 and 3 ). Titration of our artificial construct $\left[\mathrm{Cu}_{2}(\mathrm{HXTA}-\mathrm{ArS})(\mathrm{PCV})\right]^{3-} \subset$ bCA with glyphosate allowed an indicator displacement assay into the artificial receptor with an affinity constant for glyphosate of $1.28 \bullet 10^{6} \mathrm{M}^{-1}$ (See Table 1). The incorporation of $\left[\mathrm{Cu}_{2}(\mathrm{HXTA}-\mathrm{ArS})(\mathrm{PCV})\right]^{3-}$ in bCA shows a decrease of the affinity constant for glyphosate of almost 3 times. However, it 
is consistent with the interactions with the second coordination sphere that may improve the selectivity but not necessarily the affinity.

a)

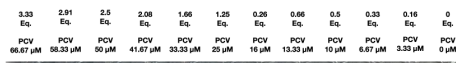

(3)
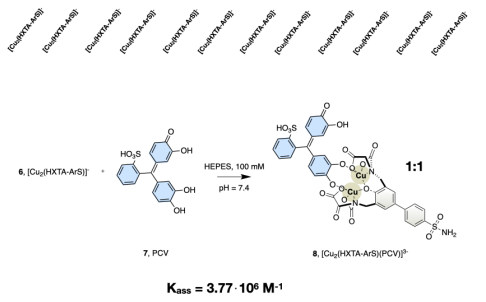

b)

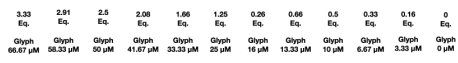
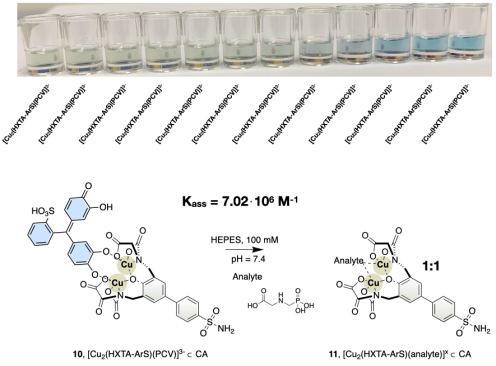

c)

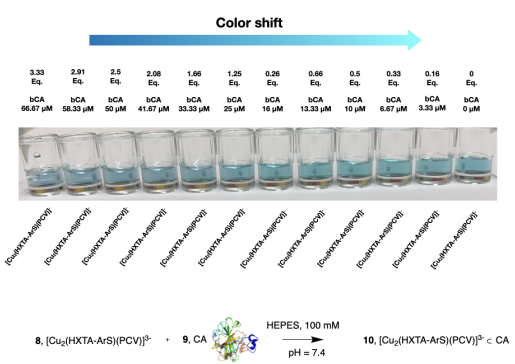

d)
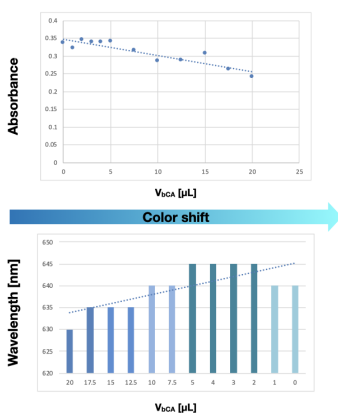

Figure 3: a) A $20 \mu \mathrm{M}$ solution of PCV is titrated with a decreasing amount of [6, $\mathrm{Cu}_{2}$ (HXTA-ArS) $]^{-}$forming a 1:1 complex. b) A $20 \mu \mathrm{M}$ solution of $\left[\mathbf{8}, \mathrm{Cu}_{2}(\mathrm{HXTA}-\right.$ $\mathrm{ArS})(\mathrm{PCV})]^{3-}$ is titrated with a decreasing amount of glyphosate of forming a 1:1 complex. c) A $20 \mu \mathrm{M}$ solution of $\left[\mathbf{1 0}, \mathrm{Cu}_{2}(\mathrm{HXTA}-\mathrm{ArS})(\mathrm{PCV})\right]^{3-}$ is titrated with a decreasing amount bCA forming a 1:1 complex. An hysochromic shift is visible uppon addition of $\left(\mathbf{1 0},\left[\mathrm{Cu}_{2}(\mathrm{HXTA}-\mathrm{ArS})(\mathrm{PCV})\right]^{3-}\right.$ to carbonic anhydrase.

\subsection{Screening}

In order to test the selectivity of our artificial receptor $\left[\mathrm{Cu}_{2}(\mathrm{HXTA}-\mathrm{ArS})(\mathrm{PCV})\right]^{3-} \subset$ $\mathrm{CA}$, we designed a small screening against various anions (See Figure 4). Two IDAreactions occured for $\left[\mathrm{Cu}_{2}(\mathrm{HXTA}-\mathrm{ArS})(\mathrm{PCV})\right]^{3-}$ : glyphosate and pyrophosphate. Some dinuclear copper complexes are described in the litterature to detect pyrophosphate under similar conditions. Incorporation of $\left[\mathrm{Cu}_{2}(\mathrm{HXTA}-\mathrm{ArS})(\mathrm{PCV})\right]^{3-}$ into carbonic anhydrase $\left(\left[\mathrm{Cu}_{2} \text { (HXTA-ArS)(PCV) }\right]^{3-} \subset \mathrm{CA}\right)$ improved the selectivity. The detection occurred only for pyrophosphate suggesting that the second coordination sphere played a crucial role in detection of substances of choice. 


\subsection{Affinity constant comparison}

The affinity constant of $\left[\mathrm{Cu}_{2}(\mathrm{HXTA}-\mathrm{ArS})\right]^{1-}$ for PCV is in the range of similar systems described in the literature (See Table 1 entry 1 and 4) albeit 10 times higher for $\left[\mathrm{Cu}_{2}(\mathrm{HXTA}-\mathrm{ArS})\right]^{1-}$. Affinity of $\left[\mathrm{Cu}_{2}(\mathrm{HXTA}-\mathrm{ArS})\right]^{1-}$ is of $\mathrm{K}_{a}=7.02 \bullet 10^{6} \mathrm{M}^{-1}$ that is about two times higher than for PCV suggesting that glyphosate has a relatively high affinity for the copper complex $\left[\mathrm{Cu}_{2}(\mathrm{HXTA}-\mathrm{ArS})\right]^{1-}$. Comparison with the literature for the recognition of PPi shows only an affinity of $\mathrm{K}_{a}=1.09 \bullet 10^{4}\left[\mathrm{M}^{-1}\right]$ for $\left[\mathrm{Cu}_{2}(\mathrm{La})(\mathrm{PCV})\right]^{2-}$ that is about 100 lower than for our complex $\left[\mathrm{Cu}_{2}(\mathrm{HXTA}-\mathrm{ArS})\right]^{1-}$ with glyphosate. When incorporated into bCA, $\left[\mathrm{Cu}_{2}(\mathrm{HXTA}-\mathrm{ArS})\right]^{1-}$ has an affinity constant of $\mathrm{K}_{a}=1.28 \bullet 10^{6}$ $\mathrm{M}^{-1}$ that is about 3 times lower than outside of the protein suggesting the influence of the second coordination sphere on the recognition of glyphosate.

\section{Results and discussion}

In summary, i) We were able to create an artificial antibody for the naked-eye detection of glyphosate. ii) Our artificial construct is able to detect selectively glyphosate over other analytes iii) The affinity constant of our system is about 10 times higher than similar described system in the litterature with and without the use of the second coordination sphere provided by the proteic scaffold. iv) Both bovine and human carbonic anhydrase can be used for the creation of artificial antibodies with $\left[6, \mathrm{Cu}_{2}(\mathrm{HXTA}-\mathrm{ArS})\right]^{-}$.

\section{Mechanism of coordination}

Investigation of recognition of analytes allows to conclude that phosphate or acetate are both not recognized by $\left[\mathrm{Cu}_{2}(\mathrm{HXTA}-\mathrm{ArS})(\mathrm{PCV})\right]^{3-} \subset \mathrm{CA}$. It suggests that this two chemical functions does not coordinate the dinuclear copper complex. In comparison, with glyphosate that possesses these two functions we can conclude that the two have a synergistic effect since the pesticide is recognized by our receptor. Literature mentions the coordination of glyphosate to metal complexes via a tripodal coordination. [20] In our case, we suggest that glyphosate coordinates the two metal complexes since we observe a displacement of pyrocathecol violet. Investigation of the literature for the coordination sphere of $[\mathrm{Cu}(\mathrm{HXTA})]$ allows to see that the coordination number is five for each cooper. [21-23] We therefore anticipate that our dinuclear complex has also a coordina-

\section{TABLE 1}

Comparison of different association constant and detection limit for various described dinuclear complexes

\begin{tabular}{ll}
\hline Systems & $\mathrm{K}_{a}\left[\mathrm{M}^{-1}\right]$ \\
\hline$\left[\mathrm{Cu}_{2}(\mathrm{HXTA}-\mathrm{ArS})\right]^{-}$for PCV & $3.77 \cdot 10^{6}$ \\
{$\left[\mathrm{Cu}_{2}(\mathrm{HXTA}-\mathrm{ArS})(\mathrm{PCV})\right]^{3-}$ for glyphosate } & $7.02 \cdot 10^{6}$ \\
{$\left[\mathrm{Cu}_{2}(\mathrm{HXTA}-\mathrm{ArS})(\mathrm{PCV})\right]^{3-} \subset \mathrm{CA}$ for glyphosate } & $1.28 \cdot 10^{6}$ \\
{$\left[\mathrm{Cu}_{2}(\mathrm{La})\right]^{4+}$ for PCV } & $3.54 \cdot 10^{5}$ \\
{$\left[\mathrm{Cu}_{2}(\mathrm{La})(\mathrm{PCV})\right]^{2-}$ for PPi } & $1.09 \cdot 10^{4}$ \\
\hline
\end{tabular}




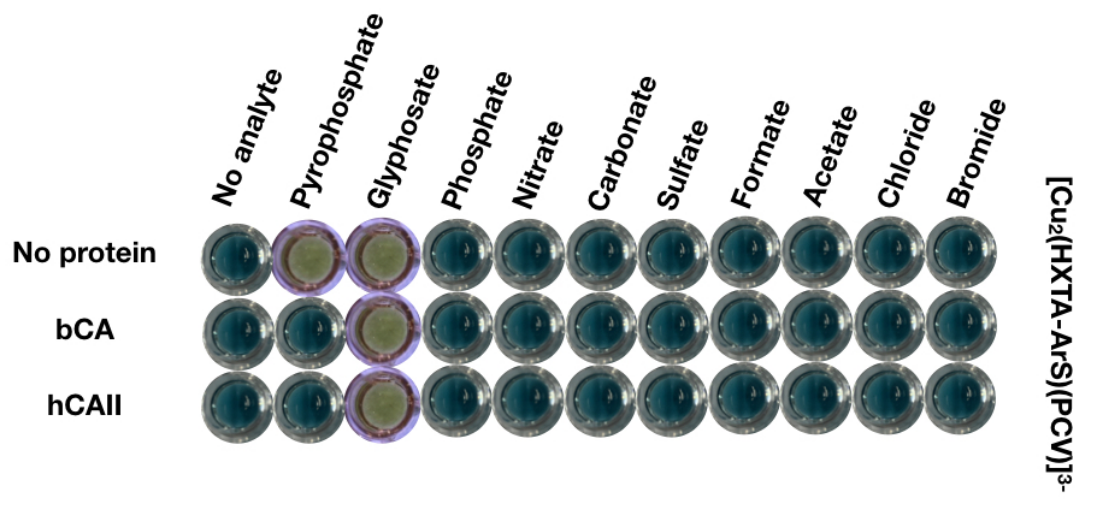

FIGURE 4: Screening of $\left[\mathrm{Cu}_{2}(\mathrm{HXTA}-\mathrm{ArS})(\mathrm{PCV})\right]^{3-} \subset \mathrm{CA}$ with various analytes for their naked-eye detection.

tion number of five for each copper. We therefore anticipate a coordination of our system as presented inFigure 5. This coordination mode is the unique possibility given the assumptions we made. In order to prove that our system is not dismantled with the addition of glyphosate, we added glyphosate to the dinuclear complex $\left[\mathrm{Cu}_{2}(\mathrm{HXTA}-\mathrm{ArS})(\mathrm{PCV})\right] 3$ a shift in color appeared immediatly after the addition of glyphosate but not solution didn't came transparent suggesting that the complexe coordinate truly the pesticide.

\section{Conclusion}

In short, we have developed a novel colorimetric sensor for glyphosate by simply mixing HXTA-ArS- $\mathrm{H}_{5}$, which can be prepared readily in high yield, in water at physiological $\mathrm{pH}$. The probe can detect glyphosate in an aqueous solution at physiological $\mathrm{pH}$, both spectrophotometrically and visually. Our system is the first described to date that offers a biomimetic platform with great potential for further development of selective binders, which may be able to target phosphorylated compounds of important analytical and therapeutic interest. 
5 coordinate proposition

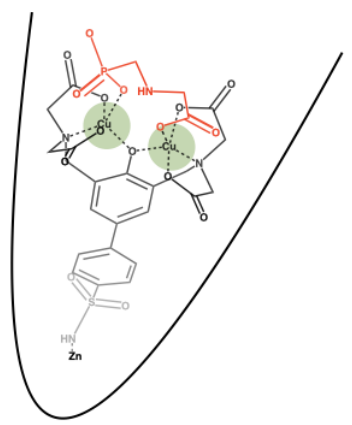

CA active site
6 coordinate proposition

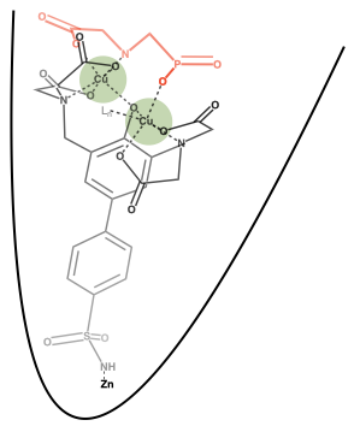

CA active site

FIGURE 5: Proposition of the coordination mechanism of glyphosate to $\left[\mathrm{Cu}_{2}(\mathrm{HXTA}-\right.$ $\mathrm{ArS})(\mathrm{PCV})]^{3-} \subset \mathrm{CA}$. The five coordinate proposition is supported by the literature. The 6 coordinate proposition allow full coordination of glyphosate to the dinuclear copper complex but is only possible for a six coordinate of copper.

\section{Acknowledgements}

We thank Prof. Thomas R. Ward for the loan of a spectrophotometer. We thank the analytical service (NPAC) of the University of Neuchâtel. Additionnaly, we thank the students that participated to the reproduction of these experiments, as well as the Gymnase français de Bienne for providing us lab equipments. We thank Cecile Hediger for the affinity constant calculations.

\section{References}

[1] S. Miersch and S. S. Sidhu, Methods, 2012, 57, 486-498.

[2] A. R. Bradbury, S. Sidhu, S. Dübel, and J. McCafferty, Nature biotechnology, 2011, 29, 245-254.

[3] S. A. Benner and A. M. Sismour, Nature Reviews Genetics, 2005, 6, 533-543.

[4] L. M. Weiner, J. C. Murray, and C. W. Shuptrine, Cell, 2012, 148, 1081-1084. 
[5] M. Nutsara, P. Supho, R. Vithaya, R. J. Ritchie, H. Itaru, O. Akio, and W. Jirarut, Scientific Reports (Nature Publisher Group), 2020, 10.

[6] M. S. Han and D. H. Kim, Angewandte Chemie International Edition, 2002, 41, 3809-3811.

[7] Y. Wu, L. Liu, S. Zhan, F. Wang, and P. Zhou, Analyst, 2012, 137, 4171-4178.

[8] F. Diederich, Angewandte Chemie International Edition in English, 1988, 27, 362386.

[9] M. AnthonyáMcKervey, Chemical Society Reviews, 1996, 25, 15-24.

[10] J. W. Steed, Coordination Chemistry Reviews, 2001, 215, 171-221.

[11] S. O. Kang, J. M. Llinares, D. Powell, D. VanderVelde, and K. Bowman-James, Journal of the American Chemical Society, 2003, 125, 10152-10153.

[12] E. S. Barrett, J. L. Irwin, A. J. Edwards, and M. S. Sherburn, Journal of the American Chemical Society, 2004, 126, 16747-16749.

[13] G. Karotsis, M. Evangelisti, S. J. Dalgarno, and E. K. Brechin, Angewandte Chemie, 2009, 121, 10112-10115.

[14] Z. Guo, I. Shin, and J. Yoon, Chemical Communications, 2012, 48, 5956-5967.

[15] S. K. Pal, H. A. Drabkin, J. A. Reeves, J. D. Hainsworth, S. E. Hazel, D. A. Paggiarino, J. Wojciak, G. Woodnutt, and R. S. Bhatt, Cancer, 2017, 123, 576-582.

[16] J. M. Wojciak, N. Zhu, K. T. Schuerenberg, K. Moreno, W. S. Shestowsky, M. Hiraiwa, R. Sabbadini, and T. Huxford, Proceedings of the National Academy of Sciences, 2009, 106, 17717-17722.

[17] R. Mesnage and M. N. Antoniou, Frontiers in public health, 2017, 5, 316.

[18] R. C. Holz, J. M. Bradshaw, and B. Bennett, Inorganic chemistry, 1998, 37, 12191225.

[19] W. Yu, J. Qiang, J. Yin, S. Kambam, F. Wang, Y. Wang, and X. Chen, Organic letters, 2014, 16, 2220-2223.

[20] D. Heineke, S. J. Franklin, and K. N. Raymond, Inorganic Chemistry, 1994, 33, 2413-2421.

[21] V. Chaurin, E. C. Constable, and C. E. Housecroft, New Journal of Chemistry, 2006, $30,1740-1744$.

[22] S. Laborda, R. Clérac, C. E. Anson, and A. K. Powell, Inorganic chemistry, 2004, 43, 5931-5943.

[23] R. C. Holz, J. M. Bradshaw, and B. Bennett, Inorganic chemistry, 1998, 37, 12191225. 